\title{
Effect of Bio-Priming on Seed Yield and Quality in Pumpkin cv. CO2
}

\author{
R. Sivakalai* and K. Krishnaveni \\ Department of Seed Science and Technology, Tamil Nadu Agricultural University, \\ Coimbatore, Tamil Nadu, India \\ *Corresponding author
}

\begin{tabular}{|c|c|}
\hline & A B S T R A C T \\
\hline & \multirow{6}{*}{$\begin{array}{l}\text { Vegetables form an important constituent in Indian diet and play a vital role in human } \\
\text { nutrition. The experiment was carried out under field condition to study the effect of seed } \\
\text { biopriming with various biopriming agents (Azospirillum, Phosphobacteria, Pseudomonas } \\
\text { fluorescens) on yield and yield components of pumpkin cv. CO2. Under laboratory } \\
\text { condition it was found that, the best biopriming treatments were non primed seed, } \\
\text { hydropriming, biopriming with Phosphobacteria } 20 \%+\text { Pseudomonas fluorescens } 20 \% \text {, } \\
\text { biopriming with Azospirillum } 10 \%+\text { Phosphobacteria } 20 \%+\text { Pseudomonas fluorescens } \\
20 \% \text {. The performance and productivity of bioprimed seeds under field conditions brought } \\
\text { out the positive influence of seeds bioprimed with Azospirillum } 10 \%+\text { Phosphobacteria } \\
20 \%+\text { Pseudomonas fluorescens } 20 \% \text { for } 12 \mathrm{hr} \text { maximizing the plant growth and } \\
\text { development, seed yield and quality of resultant seed. The seed yield for this treatment was } \\
304 \mathrm{~kg} \mathrm{ha}^{-1} \text { which accounted for } 21 \text { per cent increase over the non-primed seed. }\end{array}$} \\
\hline & \\
\hline & \\
\hline & \\
\hline Article Info & \\
\hline $\begin{array}{l}\text { Accepted: } \\
\text { 04 October } 2017 \\
\text { Available Online: } \\
\text { 10 December } 2017\end{array}$ & \\
\hline
\end{tabular}

\section{Introduction}

Pumpkin (Cucurbita moschata) is a gourdlike squash of the genus Cucurbita and the family Cucurbitaceae and is native to North America. Pumpkin is one of the widely grown vegetables rich in vital antioxidants, vitamin A, flavonoids, poly-phenolics, antioxidants and terpenoids such as leutin, xanthin and carotenes in abundance.

An improved diet is supposed to have $300 \mathrm{~g}$ of vegetables per day per capita, but the average per capita vegetable consumption is reported to be only $120 \mathrm{~g}$ in India. The main reason attributed for this is non-availability of adequate quantity of quality seeds. Since, a successful vegetable production is very dependent upon a sustainable supply of quality seeds. Pumpkins are monoecious having both male and female flowers on the same plant. The female flower is distinguished by the small ovary at the base of the petals.

The color of pumpkin is derived from the orange pigments abundant in them. The main nutrients are leutin and both alpha and beta carotene, the latter of which generates vitamin $\mathrm{A}$ in the body. Pumpkins are grown all around the world for a variety of reasons ranging from agricultural purposes to commercial and ornamental sales.

The biggest international producers of pumpkins include the United States, Canada, 
Mexico, India and China. In India, it is grown mainly in Assam, West Bengal, Tamil Nadu, Karnataka, Madhya Pradesh, Uttar Pradesh, Orissa and Bihar. Many researchers have developed new technologies called "Seed Enhancement Techniques" for improving the quality of seeds before sowing.

Seed priming is the soaking of seeds in a solution of any priming agent followed by drying of seeds that initiates seed germination related process without radical emergence (McDonald, 1999). Various seed priming techniques have been developed including hydro, halo, osmo, thermo, solid matrix and biopriming (Ashraf and Foolad, 2005).

The beneficial effects of priming have been demonstrated for many field and horticultural crops such as barley (Abdulrahmani et al., 2007), maize (Parera and Cantliffe, 1994a), lentil (Ghassemi-Golezani et al., 2008a), chickpea (Ghassemi-Golezani et al., 2008b), sugar beet (Sadeghian and Yavari, 2004) and sunflower (Singh, 1995).

\section{Materials and Methods}

The experiment was laid out in Agricultural Research Station at Bhavanisagar in Randomized Block Design with four treatment combinations replicated five. The size of plot was $4 \times 10 \mathrm{~m}^{2}\left(40 \mathrm{~m}^{2}\right)$ with a spacing of $2 \times 2 \mathrm{~m}$ with a pit size of $30 \times 30 \times$ $30 \mathrm{~cm}$. Observations on growth and yield characters were recorded at harvest. Experimental details are as follows:

\section{Treatment details}

$\mathrm{T}_{0}$ - Nonprimed seed

$\mathrm{T}_{1}$ - Hydropriming for $12 \mathrm{~h}$

$\mathrm{T}_{2}$ - Biopriming with Phosphobacteria $20 \%$ + Pseudomonas fluorescens $20 \%$ for $12 \mathrm{~h}$
$\mathrm{T}_{3}$ - Biopriming with Azospirillum $10 \%+$ Phosphobacteria $20 \%+$ Pseudomonas fluorescens $20 \%$ for $12 \mathrm{~h}$.

\section{Seed yield characters}

\section{Number of fruits plant ${ }^{-1}$}

The number of fruits harvested from randomly selected ten plants were counted and recorded and the mean values were expressed in whole number.

\section{Weight of fruit plant ${ }^{-1}$}

The fruits harvested from each plant were weighed separately and the mean values were expressed in gram.

\section{Number of seeds fruit ${ }^{-1}$}

Ten fruits were randomly selected from each treatment replication wise from pickings and the seeds were extracted from individual fruits and counted separately.

The mean values were expressed in number.

\section{Seed weight fruit ${ }^{-1}$}

The fruits harvested from each treatment after extraction were weighed separately and the mean value was expressed in $\mathrm{kg}_{\text {fruit }}{ }^{-1}$.

\section{Fruit to seed recovery}

The fruits harvested from each treatment were weighed and the seeds extracted were weighed separately.

The fruit to seed recovery was worked out as follows and expressed as per cent.

Dry weight of the seeds Fruit to seed recovery $(\%)=------------\times 100$

Weight of the fruits 


\section{Seed yield plot $^{-1}$}

The seeds obtained from all the fruits harvested from the plot were extracted cleaned, weighed and the mean value was worked out.

Then the seed yield plot $^{-1}$ was worked out based on the number of plants plot $^{-1}$ and expressed as kg plot ${ }^{-1}$.

\section{Seed yield ha ${ }^{-1}$}

Seed yield $\mathrm{ha}^{-1}$ was arrived by computation using seed yield per plot and expressed in $\mathrm{kg}$ $\mathrm{ha}^{-1}$.

\section{Seed quality characters}

\section{Seed recovery}

The resultant bulk seeds from each treatment were size graded using BSS 4 wire mesh sieve or 16/64" round perforated metal sieve.

The seeds retained on each sieve were weighed individually and seed recovery was calculated using the following formula and mean was expressed as seed recovery in per cent.

Weight of the seeds retained on sieve Seed recovery $(\%)=$--------------- x 100 Total weight of the seed

The seed retained by BSS $4 \times 4$ wire mesh sieve was selected for assessing the following seed quality.

\section{Hundred seed weight}

One hundred seeds were taken from the seeds retained by BSS $4 \times 4$ sieve from each treatment, replication wise, weighed and the mean was expressed as 100 seed weight in gram.

\section{Results and Discussion}

One of the most important problems facing the farmers in developing countries is the heterogeneity and lack of suitable conditions in soil that causes decreasing in germination percentage, unbalanced seedling growth for environmental conditions such as light, nutrient and water. Hence, the present experiment was initiated to study the effect of seed biopriming with various biopriming agents (Azospirillum, Phosphobacteria, Pseudomonas fluorescens), on yield and yield components of pumpkin cv.CO 2.

The yield attributing parameters viz., number of fruit plant ${ }^{-1}$ and weight of fruit plant ${ }^{-1}$, number of seeds fruit ${ }^{-1}$ and weight of seeds fruit $^{-1}$ were higher when seeds were bioprimed with Azospirillum $10 \%+$ Phosphobacteria $20 \%+$ Pseudomonas fluorescens $20 \%$ for $12 \mathrm{~h}$ (Table 1).

This accounted for 40, 57, 23 and 36 per cent increase over the nonprimed seed, respectively.

Fruit to seed recovery, seed yield plot $^{-1}$, seed yield ha ${ }^{-1}$ (Fig. 1), seed recovery and 100 seed weight were also higher in $\mathrm{T} 4$ treatment and the per cent increases over nonprimed seed were $22,20,21,10$ and 15 per cent, respectively.

Similar results were reported for many crops where seed treatments with Pseudomonas fluorescens have increased growth parameters like height, leaf area, fruit length, girth, circumference and 100 seed weight (Suslow and Schroth, 1982; Schippers et al., 1987; Wei et al., 1996; Umesha et al., 1998; Lazarovits and Nowak, 1997; Barka et al., 2000; Niranjan Raj et al., 2003a). Similarly, Aamir et al., (2013) showed that number of pods and yield were higher in mung bean treated with rhizobium and PGPR. 
Fig.1 Effect of biopriming on seed yield of pumpkin seeds

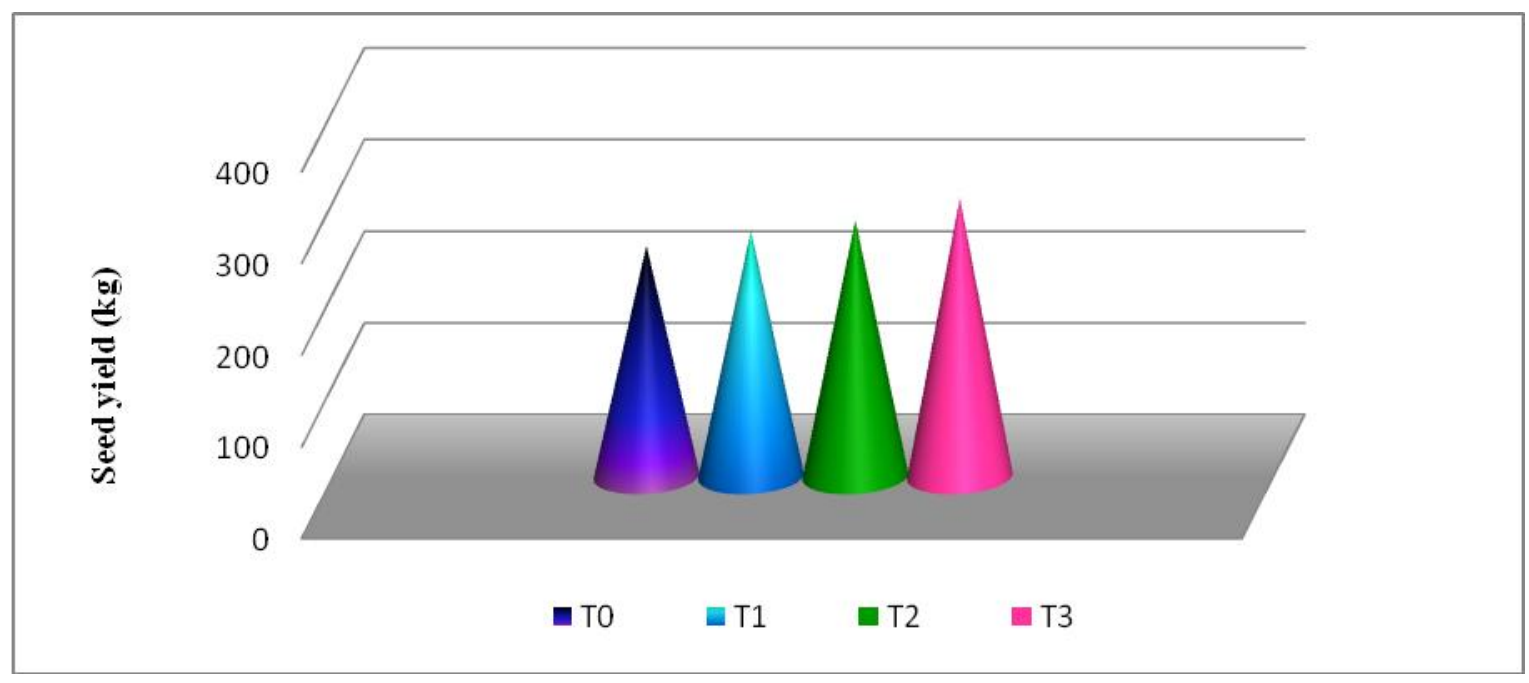

Table.1 Effect of seed biopriming on yield and yield attributing characters of pumpkin cv. CO2

\begin{tabular}{|c|c|c|c|c|c|c|c|c|c|}
\hline $\begin{array}{c}\text { Biopriming } \\
\text { treatments } \\
(\mathrm{T})\end{array}$ & $\begin{array}{l}\text { No of } \\
\text { fruit } \\
\text { plant }^{-1}\end{array}$ & $\begin{array}{c}\text { Weight } \\
\text { of fruit } \\
\text { plant }^{-1} \\
(\mathrm{~kg})\end{array}$ & $\begin{array}{l}\text { No of } \\
\text { seeds } \\
\text { fruit }^{-1}\end{array}$ & $\begin{array}{l}\text { Seeds } \\
\text { weight } \\
\text { fruit }^{-1} \\
(\mathrm{~g})\end{array}$ & $\begin{array}{c}\text { Fruits to } \\
\text { seed } \\
\text { recovery } \\
(\%)\end{array}$ & $\begin{array}{l}\text { Seed } \\
\text { yield } \\
\text { plot }^{-1} \\
(\mathbf{k g})\end{array}$ & $\begin{array}{c}\text { Seed } \\
\text { yield } \\
\text { ha }^{-1} \\
(\mathrm{~kg})\end{array}$ & $\begin{array}{l}\text { Seed } \\
\text { recovery } \\
(\%)\end{array}$ & $\begin{array}{c}100 \text { seed } \\
\text { weight } \\
\text { (g) }\end{array}$ \\
\hline $\mathbf{T}_{0}$ & 4.0 & 7.7 & 102.9 & 10.8 & 0.64 & 1.01 & 252 & 68 & 10.9 \\
\hline $\mathbf{T}_{1}$ & 4.5 & 9.0 & 113.5 & 12.6 & 0.70 & 1.07 & 268 & 70 & 11.8 \\
\hline $\mathbf{T}_{2}$ & 5.3 & 10.4 & 119.5 & 14.3 & 0.75 & 1.12 & 280 & 75 & 12.0 \\
\hline $\mathbf{T}_{3}$ & 5.6 & 12.1 & 126.5 & 14.7 & 0.78 & 1.21 & 304 & 78 & 12.5 \\
\hline Mean & 4.9 & 9.8 & 115.6 & 13.1 & 0.72 & 1.10 & 276 & 72.8 & 11.8 \\
\hline SEd & 0.07 & 0.09 & 1.47 & 0.14 & 0.01 & 0.03 & 6.86 & 0.52 & 0.09 \\
\hline $\operatorname{CD}(\mathbf{P}=0.05)$ & .17 & 0.21 & 3.21 & 0.32 & 0.02 & 0.06 & 14.95 & 1.14 & 0.19 \\
\hline
\end{tabular}

It is also evident for this study that seed biopriming with Azospirillum $10 \%+$ Phosphobacteria $20 \%+$ Pseudomonas fluorescens $20 \%$ for $12 \mathrm{~h}$ had given results, both by promoting the germination and increasing the yield and quality of pumpkin. Similar effectiveness of combined inoculation of Rhizobium and Phosphobacteria (Bacillus megaterium and Pseudomonas striata) in red gram, black gram, green gram and Bengal gram increased the grain yield. Similarly, Baser-Kouchebagh et al., (2013) showed that biopriming with Azospirillum, Azotobacter, Pseudomonas, increase the crop growth rate, yield and quality on medicinal plants.
Sakthivel et al., (2009) reported that the combined treatment (Pseudomonas + Azotobacter + Azospirillum) have higher fruit yield in tomato variety PKM-1.

Gravel et al., (2007) reported the capacity of two microorganisms, Pseudomonas putida subgroup B strain1 and Trichoderma atroviride, to promote the reproductive growth of tomato plants under typical hydroponic growing conditions. The plant growth stimulation is, most likely, the synergic result of numerous modes of action exhibited by each microorganism tested, including a regulation in the concentration of 
IAA in the rhizosphere and a regulation of the concentration of ethylene within the roots. They showed that Pseudomonas putida subgroup B strain1 and Trichoderma atroviride could be used as plant growthpromoting microorganisms to improve the productivity of greenhouse tomato crops under hydroponic conditions in inert or organic media.

\section{References}

Aamir, M., A. Aslam, M. Yahya Khan, M. Usman Jamshaid, M. Ahmad, H. Naeem Asghar and Z. Ahmad Zahir. 2013. Coinoculation with rhizobium and plant growth promoting rhizobacteria (PGPR) for inducing salinity tolerance in mung bean under field condition of semi-arid climate. Asian J. Agri. Biol., 1.

Abdulrahmani, B., K. Ghassemi-Golezani, M. Valizadeh and V. Feizi-Asl. 2007. Seed priming and seedling establishment of barley (Hordeum vulgare L.). J. Food. Agri. Environ., 5, 179-184.

Ashraf, M. and M. R. Foolad. 2005. Presowing seed treatment: A shotgun approach to improve germination, plant growth and crop yield under saline and non-saline conditions. Adv. Agron., 88: 223-271.

Barka, E. A., S. Kalantari, J. Makhlouf and J. Arul. 2000. Impact of UV-C irradiation on the cell wall-degrading enzymes during ripening of tomato (Lycopersicon esculentum L.) fruit. J. Agric. Food Chem., 48: 667-671.

Baser-kouchebagh, S., M. Hoseini, B. Mirshekari and M. Yusefi. 2013. Biopriming influence on medicinal plants germination and growth. International Journal of Biosciences, 3(6): 98-103.

Ghassemi-Golezani, K., A. A. Aliloo, M. Valizadeh and M. Moghaddam. 2008a. Effects of different priming techniques on seed invigoration and seedling establishment of lentil (Lens culinaris Medik). J. Food. Agri. Environ., 6:222226.

Ghassemi-Golezani, K., P. SheikhzadehMosaddegh and M. Valizadeh. 2008b. Effects of hydro-priming duration and limited irrigation on field performance of chickpea. Res. J. Seed Sci., 1:34-40.

Gravel, V., H. Antoun and R. J. Tweddell. 2007. Growth stimulation and fruit yield improvement of greenhouse tomato plants by inoculation with Pseudomonas putida or Trichoderma atroviride: possible role of indole acetic acid (IAA). Soil Biology and Biochemistry, 39: 1968-1977.

Lazarovits, G. and J. Nowak. 1997. Rhizobacteria for improvement of plant growth and establishment. Hort. Science, 32:188-192.

McDonald, M.B. 1999. Seed deterioration: Physiology, repair and assessment. Seed Sci. Technol., 27: 177-237.

Niranjan Raj, S., G. Chaluvaraju, K. N. Amruthesh, H. S. Shetty, M. S. Reddy and

J. W. Kloepper. 2003a. Induction of growth promotion and resistance against downy mildew on pearl millet (Pennisetum glaucum) by rhizobacteria. Plant Dis., 87: 380-384.

Parera, C. and D.J. Cantliffe. 1994a. Dehydration rate after solid matrix priming alters seed performance of shrunken-2 corn. J. Am. Soc. Hort. Sci., 11: 629-635.

Sadeghian, S. Y. and N. Yavari. 2004. Effect of warer-deficit stress on germination and early seedling growth in sugar beet. J. Agron. Crop Sci., 190:138-144.

Sakthivel, U., S. Mahalakshmi and B. Karthikeyan. 2009. Studies on isolation and characterisation and its effect of seed inoculation of PGPR (pseudomonas fluorescens) on yield of 
tomato. Journal of Phytology, 1(1): 3339.

Schippers, B., A. W. Bakker, and P. A. H. M. Bakker, 1987. Interactions of deleterious and beneficial rhizosphere microorganisms and the effect of cropping practices. Annual Review of Phytopathology, 25: $339-358$.

Singh, B. G. 1995. Effect of hydrationdehydration seed treatments on vigour and yield of sunflower. Ind. J. Plant Physiol., 38:66-68.

Suslow, T. V. and M. N. Schroth. 1982. Rhizobacteria of sugar beets: Effects of seed application and root colonization on yield. Phyto Pathology, 72: 199-206.

Umesha, S., S. M. Dharmesh, A. Shetty, M. Krishnappa and H. S. Shetty. 1998. Biocontrol of downy mildew disease of pearl millet using Pseudomonas fluorescens. Crop Protect, 17(5): 387390.

Wei, D., K. Kirimura, S. Usami and T. Lin. 1996. Purification and characterization of an extracellular $\beta$-glucosidase from the wood-grown fungus Xylaria regalis. Current Microbiology, 33 (5): 297-301.

\section{How to cite this article:}

Sivakalai, R. and Krishnaveni, K. 2017. Effect of Bio-Priming on Seed Yield and Quality in Pumpkin cv. CO2. Int.J.Curr.Microbiol.App.Sci. 6(12): 85-90. doi: https://doi.org/10.20546/ijcmas.2017.612.011 